\title{
Urinary $p$-cresol is elevated in young French children with autism spectrum disorder: a replication study
}

\author{
Stefano Gabriele ${ }^{1,2} \#$, Roberto Sacco ${ }^{1,2} \#$, Sonia Cerullo ${ }^{1,2} *$, Cristina Neri ${ }^{3,4}$, Andrea Urbani ${ }^{3,4}$, Gabriele Tripi $^{5,6}$, \\ Joëlle Malvy ${ }^{7}$, Catherine Barthelemy ${ }^{7}$, Frédérique Bonnet-Brihault ${ }^{7}$, and Antonio M. Persico ${ }^{1,2,8} \#$ \\ ${ }^{1}$ Unit of Child and Adolescent NeuroPsychiatry and ${ }^{2}$ Laboratory of Molecular Psychiatry and Neurogenetics, University Campus Bio-Medico, Rome, \\ Italy, ${ }^{3}$ Department of Internal Medicine, University Tor Vergata, Rome, Italy, ${ }^{4}$ Department of Experimental Neurosciences, I.R.C.C.S. "Fondazione S. \\ Lucia", Rome, Italy, ${ }^{5}$ Department PROSAMI, University of Palermo, Italy, ${ }^{6}$ Childhood Psychiatric Service for Neurodevelopmentals Disorders, \\ CH Chinon, France, ${ }^{7}$ Imagerie et cerveau INSERM: U930, Université François Rabelais, Hôpital Bretonneau, Tours, France, and ${ }^{8}$ Mafalda Luce Center \\ for Pervasive Developmental Disorders, Milan, Italy
}

\begin{abstract}
The aromatic compound $p$-cresol (4-methylphenol) has been found elevated in the urines of Italian autistic children up to 8 years of age. The present study aims at replicating these initial findings in an ethnically distinct sample and at extending them by measuring also the three components of urinary $p$-cresol, namely $p$-cresylsulfate, $p$-cresylglucuronate and free $p$-cresol. Total urinary $p$-cresol, $p$-cresylsulfate and $p$-cresylglucuronate were significantly elevated in 33 French autism spectrum disorder (ASD) cases compared with 33 sex- and age-matched controls $(p<0.05)$. This increase was limited to ASD children aged $\leq 8$ years $(p<0.01)$, and not older $(p=0.17)$. Urinary levels of $p$-cresol and $p$-cresylsulfate were associated with stereotypic, compulsive/repetitive behaviors $(p<0.05)$, although not with overall autism severity. These results confirm the elevation of urinary $p$-cresol in a sizable set of small autistic children and spur interest into biomarker roles for $p$-cresol and $p$-cresylsulfate in autism.
\end{abstract}

\author{
Keywords \\ Gut flora, neurotoxicity, organic \\ contaminants, $p$-cresylsulfate, \\ pervasive developmental disorders
}

\section{History}

Received 22 May 2014

Accepted 17 June 2014

Published online 10 July 2014

\section{Introduction}

Autism spectrum disorder (ASD) is a neurodevelopmental disorder characterized by impaired social interaction and communication, as well as by restricted patterns of interest and stereotyped behaviors (American Psychiatric Association, 2013). This is one of the most frequent disorders in child psychiatry, with an incidence of 1/68 newborns according to recent estimates by the Center for Disease Control (Developmental Disabilities Monitoring Network Surveillance Year 2010 Principal Investigators and Centers for Disease Control and Prevention, 2014). It displays a broad variety of clinical signs, severity, developmental trajectory and treatment response. This striking clinical heterogeneity seemingly reflects an equally impressive etiological heterogeneity, where causes underlying ASD are complex and remain elusive in the majority of patients. Most ASD cases are compatible with a "multiple hit" model, whereby several inherited and/or

\#Stefano Gabriele, Roberto Sacco and Antonio M. Persico are responsible for statistical design/analysis. E-mail: s.gabriele@unicampus.it; r.sacco@unicampus.it; a.persico@unicampus.it

*Current address: Department of Child Neurology and Psychiatry, Stella Maris Scientific Institute, Pisa, Italy.

Address for correspondence: Prof. Antonio M. Persico, Unit of Child and Adolescent NeuroPsychiatry, University "Campus Bio-Medico", Via Alvaro del Portillo 21, I-00128 Rome, Italy. Tel: +39-06225419155. E-mail: a.persico@unicampus.it de novo genetic variants, in combination with environmental factors especially active during prenatal life, yield abnormal neurodevelopment through "personalized" gene-gene and gene-environment interactions (Leblond et al., 2012; Persico $\&$ Napolioni, 2013). The contribution of environmental factors on top of genetic liability is supported by multiple lines of evidence, recently reviewed elsewhere (Persico \& Merelli, in press). Developmental neurotoxicants and immune challenges have been linked to autistic behaviors following prenatal exposure typically occurring during the I and II trimester of pregnancy, respectively (Persico \& Merelli, in press). Finally, an additional layer of pathophysiological complexity is conferred by the frequent involvement of other compartments outside the central nervous system, such as the immune and gastrointestinal (GI) systems (Jyonouchi et al., 2011; Wang \& Kasper, 2014).

p-cresol (4-methylphenol), an organic molecule belonging to the cresol class of aromatic compounds (OECD, 2003), has recently become the object of our interest as an environmental factor possibly involved in ASD. Environmental exposure to $p$-cresol is relatively common and its absorption can occur through the skin, the GI system and the respiratory tract; however, the most common source of this compound is represented by some gut bacteria, such as Clostridium difficile, able to push the fermentation of tyrosine or toluene up to $p$-cresol, by means of synthetic enzymes not present in human cells (for review see Persico \& Napolioni, 2012). 
Traveling in the blood, $p$-cresol is mostly protein-bound, as a partially lipophilic compound (Bergé-Lefranc et al., 2010). Approximately $95 \%$ of total plasma $p$-cresol is metabolized to $p$-cresylsulfate through $\mathrm{O}$-sulfonation, which occurs primarily in colon and liver; the remaining $3-4 \%$ is metabolized to $p$-cresylglucuronide through glucuronidation, which takes place only in the liver (De Bruin, 1976; Mandel, 1971; Ramakrishna et al., 1991). Only $0.5-1 \%$ of total plasma $p$-cresol is in free form. $p$-cresol and its conjugation derivates $p$-cresylsulfate and $p$-cresylglucuronide are then filtered from the blood stream at the glomerular level and can be found in the urines of all individuals in small amounts (Bone et al., 1976; Renwick et al., 1988).

We were interested in contrasting urinary $p$-cresol levels in autistic and typically developing children because ASD has been associated with enhanced frequencies of (1) excessive gut permeability, reported by at least some (D'Eufemia et al., 1996; De Magistris et al., 2010), though not all studies (Robertson et al., 2008) and (2) gut infection with cresolproducing C. difficile (Finegold et al., 2002; De Angelis et al., 2013; Keşli et al., 2014; Selmer \& Andrei, 2001; Wang et al., 2011). Our initial study reported significantly elevated amounts of urinary $p$-cresol in 59 Italian ASD children compared with 59 age- and sex-matched controls $(p<0.05)$ (Altieri et al., 2011). In particular, urinary $p$-cresol was significantly elevated in ASD children only between the ages of 2 and $8 \quad(p<0.01)$, more frequently in females $(p<0.05)$, and in more severely autistic children regardless of sex $(p<0.05)$. These initial findings suggested that urinary $p$-cresol could represent a potential biomarker defining a consistent subgroup of small ASD children, and may play a pathomorphic role by increasing autism severity. The present study aims at replicating and extending our initial results in an independent and ethnically distinct sample of ASD patients and matched controls. We thus (a) performed high-performance liquid chromatography with fluorescence detector (HPLC-FLD) measurements of total urinary $p$-cresol and its derivates $p$-cresylsulfate and $p$-cresylglucuronate in an independent sample of 33 French ASD individuals and in 33 age- and sex-matched typically developing controls, and (b) assessed demographic as well as developmental, family history and clinical correlates of urinary $p$-cresol levels.

\section{Methods}

\section{Patient sample}

A sample of 33 idiopathic ASD patients was recruited at the Center for Child and Adolescent Psychiatry of the Hôpital Bretonneau in Tours (France). Their demographic and clinical characteristics are summarized in Table 1. Tight sex- and agematching ( $\pm 1 \mathrm{yr}$ ) was applied to recruit 33 typically developing controls devoid of any overt ASD symptomatology among the offspring of clinical/academic personnel. Cases and controls were Caucasians of French ethnicity (with exception for eight cases of African, and four of mixed ethnicity), with mean age $( \pm$ S.E.M.) of $7.90 \pm 0.57$ and $7.60 \pm 0.61 \mathrm{yrs}$, respectively (Student $t=0.364,64 \mathrm{df}, p=0.717$ ), and an M:F ratio of 7.2:1 for both. All parents gave written informed consent for their children, using the consent form approved by the Ethical
Table 1. Demographical and clinical characteristics of the French ASD sample.

\begin{tabular}{|c|c|c|c|c|}
\hline & $N$ & Mean/1 & median & Range \\
\hline \multicolumn{5}{|c|}{ Age in yrs (mean \pm S.E.M.) } \\
\hline & 33 & 7.90 & 0.57 & $4-16$ \\
\hline & $N$ & \multicolumn{3}{|c|}{ Percent } \\
\hline \multicolumn{5}{|l|}{ Gender } \\
\hline Male & 29 & \multicolumn{3}{|c|}{$87.9 \%$} \\
\hline Female & 4 & \multicolumn{3}{|c|}{$12.1 \%$} \\
\hline $\mathrm{M} / \mathrm{F}$ ratio & $7.2: 1$ & & & \\
\hline \multicolumn{5}{|l|}{ DSM-IV diagnosis } \\
\hline Autistic disorder & 24 & \multicolumn{3}{|c|}{$72.7 \%$} \\
\hline Asperger syndrome & 2 & \multicolumn{3}{|c|}{$6.1 \%$} \\
\hline PDD-NOS & 7 & \multicolumn{3}{|c|}{$21.2 \%$} \\
\hline \multicolumn{5}{|l|}{ I.Q. $(N=33)$} \\
\hline$>70$ & 13 & \multicolumn{3}{|c|}{$39.4 \%$} \\
\hline$\leq 70$ & 20 & \multicolumn{3}{|c|}{$60.6 \%$} \\
\hline
\end{tabular}

Total $N=33$.

Committee of University "Campus Bio-Medico" (Rome, Italy).

Diagnostic screening procedures used to exclude syndromic forms have been previously described (Sacco et al., 2010). Briefly, patients fulfilling Diagnostic and Statistical Manual IV (DSM-IV) diagnostic criteria for Autistic Disorder, Asperger Disorder or PDDNOS were screened for nonsyndromic autism using MRI, EEG, audiometry, urinary aminoacid and organic acid measurements, cytogenetic and fragile- $X$ testing. Patients with gross dysmorphic features were excluded even in the absence of detectable cytogenetic alterations. Patients with sporadic seizures (i.e. $<1$ every 6 months) were included; patients with frequent seizures or focal neurological deficits were excluded.

Autistic behaviors were assessed using the Autism Diagnostic Observation Schedule (ADOS) (Lord et al., 2002), the Autism Diagnostic Interview - Revised (ADI-R) (Rutter et al., 2003), the Children Autism Rating Scales (CARS) (Schopler et al., 1986), the Évaluation des Comportements Autistiques - version révisée (ECA-R) (Barthélémy et al., 1997), the Échelle d'évaluation des Comportements répétés et restreints (EC2R) (Bourreau et al., 2009) and the Évaluation Fonctionelle des Comportements - version revisée (RFC-R) (Adrien et al., 2001). I.Q. was determined using the Griffith Mental Developmental Scales (Griffith, 1970), the Brunet-Lézin scales (Brunet \& Lézin, 1976), the Echelles différentielles d'Efficience Intellectuelle (EDEI-R) (Perron-Borrel, 1996), and the Wechsler Intelligence Scale for Children - Revised (WISC-R) (Wechsler, 2005). Developmental, clinical and family history variables were characterized using an updated version of the previously described questionnaire (Sacco et al., 2010). The complete list of all variables is reported in Supplementary Table S1.

\section{Urine collection and $p$-cresol measurement by HPLC}

First-morning urines were collected at home by parents using sterile containers and were brought to the clinical center the same morning in wet ice. Urine samples were then frozen, shipped in dry ice, and stored at $-80^{\circ} \mathrm{C}$ until analysis. 
Urinary $p$-cresol concentrations were measured by HPLCFLD. Total urinary $p$-cresol concentrations were quantified after acid hydrolysis as previously described (Altieri et al., 2011). Urinary $p$-cresylsulfate levels were measured applying a selective hydrolysis of sulfate groups by using a sulfatase. Thus, $100 \mu 1$ of urines were mixed with $5 \mu$ l of internal standard ( $t$-butyl phenol $1 \mathrm{mg} / \mathrm{ml}$, Sigma-Aldrich, St. Louis, $\mathrm{MO}), 5 \mu \mathrm{l}$ of $2.5 \mathrm{M}$ Tris $\mathrm{HCl}(\mathrm{pH} 7.5)$ and $5 \mu \mathrm{l}$ of a solution containing sulfatase from Aerobacter aerogenes (SigmaAldrich, St. Louis, MO). Urinary $p$-cresylglucuronide levels were measured applying a selective hydrolysis of glucuronate groups by using a $\beta$-glucoronidase. In this case, $100 \mu \mathrm{l}$ of urines were mixed with $5 \mu \mathrm{l}$ of internal standard (as above), $5 \mu \mathrm{l}$ of $4 \mathrm{M}$ sodium acetate $(\mathrm{pH} 5.0)$, and $5 \mu \mathrm{l}$ of a solution containing $\beta$-glucoronidase type B-10 from bovine liver (Sigma-Aldrich, St. Louis, MO). Free $p$-cresol levels were measured using $100 \mu \mathrm{l}$ of urines treated with $100 \mu \mathrm{l}$ of acetonitrile. Mixes were then incubated for $2 \mathrm{~h}$ at $37^{\circ} \mathrm{C}$, kept on ice for $15 \mathrm{~min}$ and centrifuged at $12000 \mathrm{~g}$. Supernatants were transferred into fresh tubes and injected separately for HPLC analysis, using the Thermo Scientific ${ }^{\mathrm{TM}}$ Dionex $^{\mathrm{TM}}$ UltiMate $^{\mathrm{TM}} 3000$ HPLC system with fluorescence detector ( $\lambda$ ex: $270 \mathrm{~nm}, \lambda$ em: $305 \mathrm{~nm}$ ), column Dionex Acclaim ${ }^{\circledR} 120$ $\mathrm{C} 185 \mu \mathrm{m} 120 \mathrm{~A}^{\circ} 4.6 \times 150 \mathrm{~mm}$, temperature at $28^{\circ} \mathrm{C}$. The mobile phase consisted of (A): $\mathrm{H}_{2} \mathrm{O} /$ Acetonitrile (90/10)/ trifluoroacetic acid (TFA) $0.05 \%$ and (B) acetonitrile/TFA $0.05 \%$. The gradient elution program was: $0-15 \mathrm{~min}, 0-50 \%$ B; 15-17 min, $50-100 \%$ B; 17-20 min $100 \%$ B; 20-21 min $100-50 \% \mathrm{~B} ; 21-25 \mathrm{~min} 0 \% \mathrm{~B}$; the flow rate was $1 \mathrm{ml} / \mathrm{min}$. Spiked samples were run to determine the efficiency of
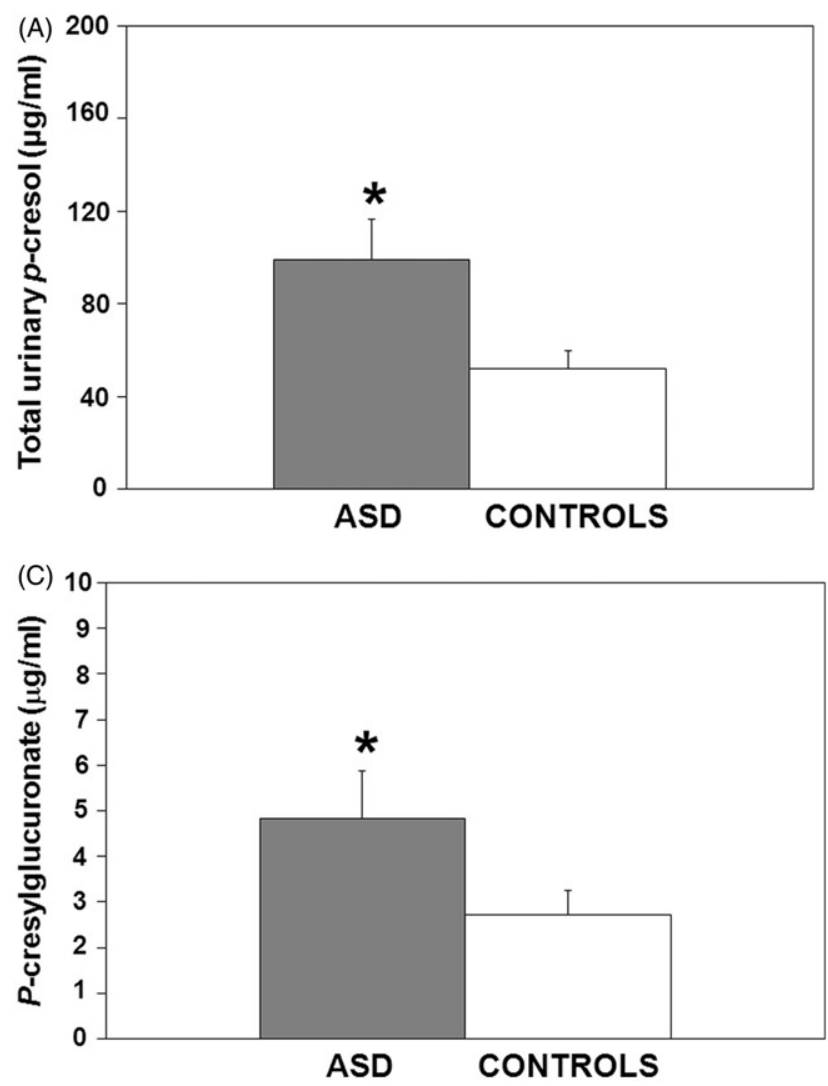

$p$-cresol recovery. Standard solutions at various $p$-cresol concentrations were made in MilliQ $\mathrm{H}_{2} \mathrm{O}$ /acetonitrile 5\%, from a stock $p$-cresol solution $(1 \mathrm{mg} / \mathrm{ml}$, Sigma-Aldrich). Correlation coefficient of the calibration straight lines was always $>0.999$. The limit of detection, calculated as three times the height of baseline long-term noise, was $20 \mathrm{ng} / \mathrm{ml}$, and the limit of quantification was $70 \mathrm{ng} / \mathrm{ml}$. Since creatinine excretion may be abnormally reduced in ASD children (Whiteley et al., 2006), data were normalized by urinary specific gravity.

\section{Statistical analyses}

Cases and controls were contrasted using the Wilcoxon signed-rank test. Correlation analyses between continuous variables were performed using non-parametric Kendall's $\tau$ test; categorical variables were tested using parametric Student $t$-tests or non-parametric Mann-Whitney $U$-tests depending on the normality of the distribution, as assessed using the Kolmogorov-Smirnov statistics. Given the exploratory nature of analyses involving clinical variables and their relative non-independence (Sacco et al., 2010), no correction for multiple testing was applied. Quantitative data are presented as mean \pm S.E.M. Two-tail $p$ values are reported throughout the manuscript and statistical significance is set at $p<0.05$.

\section{Results}

Mean total urinary $p$-cresol concentration was significantly higher among 33 ASD children compared with 33 matched
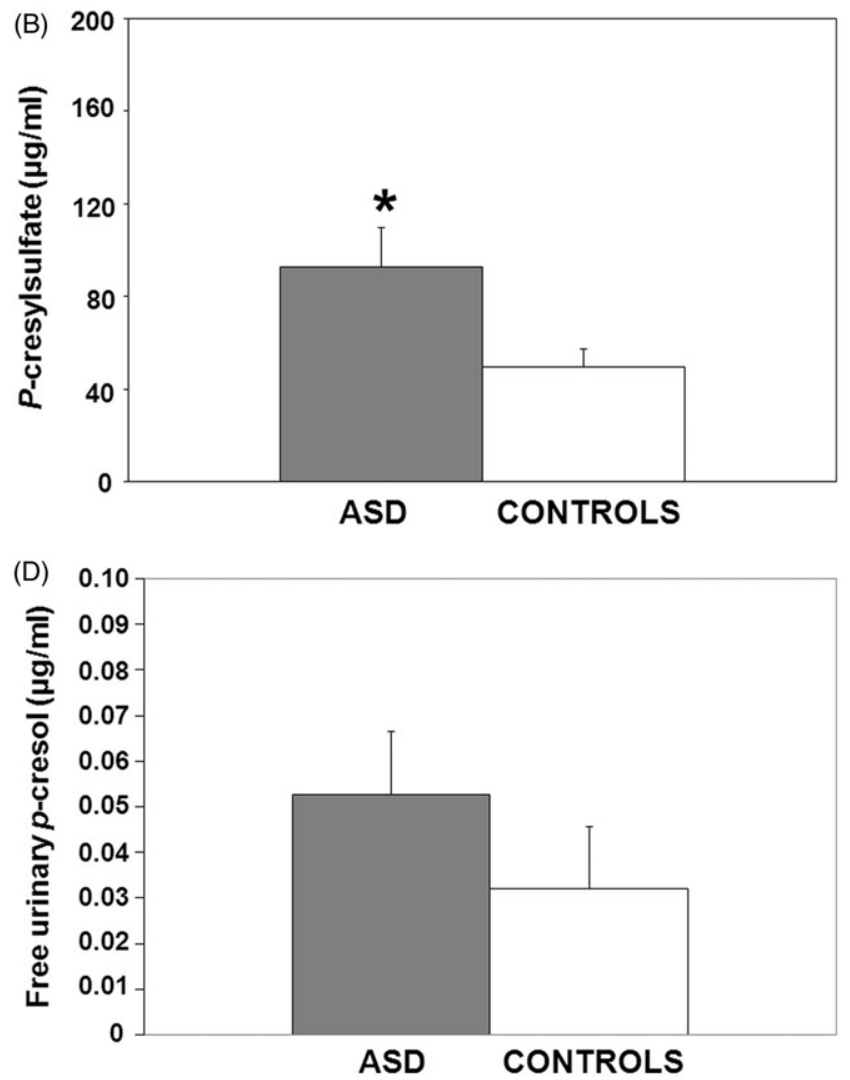

Figure 1. (A) Total urinary $p$-cresol, (B) p-cresylsulfate, (C) $p$-cresylglucuronate and (D) free urinary $p$-cresol concentrations $(\mu \mathrm{g} / \mathrm{ml})$ in 33 French ASD patients and in 33 age-matched, sex-matched and ethnically matched controls. Data are presented as mean \pm S.E.M. ${ }^{*} p<0.05$. 
controls $(98.8 \pm 17.3$ versus $52.0 \pm 7.8 \mu \mathrm{g} / \mathrm{ml}, Z=-2.743$, $p<0.05$ ) (Figure 1A). The three components, $p$-cresylsulfate, $p$-cresylglucuronate and free $p$-cresol, accounted for $94.99 \%$, $4.93 \%$ and $0.08 \%$, respectively, of total urinary $p$-cresol in ASD children and for $94.87 \%, 5.05 \%$ and $0.08 \%$ in controls. These distributions do not differ significantly $\left(\chi^{2}=0.002\right.$, $2 \mathrm{df}, p=0.99)$. $p$-cresylsulfate and $p$-cresylglucuronide derivates were also significantly elevated in ASD children compared with controls $(92.9 \pm 16.8$ versus $49.5 \pm 7.8 \mu \mathrm{g} / \mathrm{ml}$, $Z=2.564, \quad p<0.05 ; \quad 4.8 \pm 1.0 \quad$ versus $\quad 2.7 \pm 0.5 \mu \mathrm{g} / \mathrm{ml}$, $Z=-2.028, \quad p<0.05$, respectively) (Figure $1 \mathrm{~B}$ and $\mathrm{C}$ ), whereas a non-significant trend was found with free urinary $p$-cresol $(0.05 \pm 0.13$ versus $0.03 \pm 0.13 \mu \mathrm{g} / \mathrm{ml}, Z=-1.202$, $p=0.230$ ) (Figure 1D), whose concentrations were close to the sensitivity threshold of our measurement system (see Discussion).

Age-specific analyses confirmed that elevated urinary $p$-cresol levels are exclusively found in a subset of small ASD children. Applying the age-threshold of $<8$ y.o. derived from our previous results (Altieri et al., 2011), total urinary $p$-cresol levels were found significantly increased in younger $(p<0.05)$, but not older $(p=0.210$, n.s. $)$ ASD children, compared with their matched controls (Figure S1). However, greatest sensitivity/specificity was obtained in the present data set applying a slightly higher age threshold, namely $\leq 8$

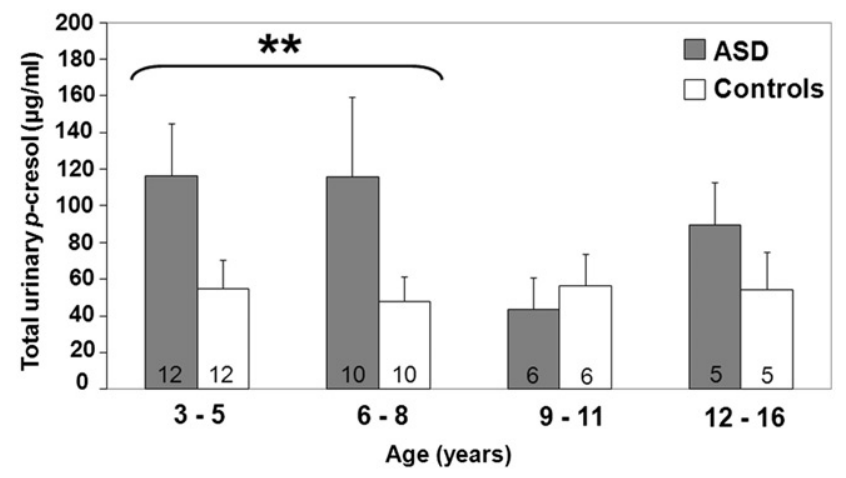

Figure 2. Total urinary $p$-cresol concentrations by age group, in 33 ASD patients (grey bars) and in 33 age-matched, sex-matched and ethnically matched controls (white bars). Data are presented as mean \pm S.E.M. Numbers inside each column represent sample sizes. ${ }^{*} p<0.01$ for global case-control contrasts in 22 pairs aged 3-8.

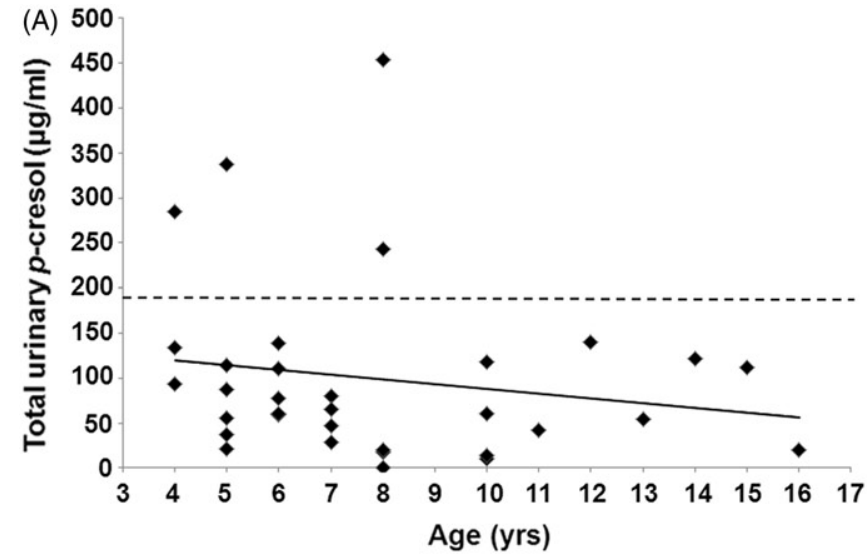

y.o., whereby total urinary $p$-cresol concentrations are very significantly elevated in ASD children below $(Z=-2.535$, $p<0.01, N=22$ case-control pairs) (Figure 2), but not above this age cut-off $(Z=-1.350, p=0.17, N=11$ case-control pairs). In particular, two French affected children, aged $8 \mathrm{y} .-3 \mathrm{~m}$. and $8 \mathrm{y}-4 \mathrm{~m}$., display total urinary $p$-cresol levels at 243.5 and $453.3 \mu \mathrm{g} / \mathrm{ml}$, respectively (Figure 3 ). Overall, $4 / 22$ (18.2\%) ASD children aged $<8$ years displayed total urinary $p$-cresol concentrations above and beyond the highest levels recorded in controls $(185.0 \mu \mathrm{g} / \mathrm{ml})$. One of these four children was a girl $(\mathrm{M}: \mathrm{F}=3: 1)$, as compared with 3 girls among 18 children with levels within the control range $(\mathrm{M}: \mathrm{F}=5: 1)$. Regression analyses confirmed a significant negative correlation of total urinary $p$-cresol concentration with age in ASD children ( $\tau=-0.223, p<0.05$, linear $R^{2}=0.030$ ) (Figure 2), but not in controls $\left(\tau=0.079, p=0.51\right.$, linear $\left.R^{2}=-0.030\right)$ (Figure S1).

No significant correlation was found between total urinary $p$-cresol, $p$-cresylsulfate or $p$-cresylglucuronate, and autism severity, based on ADOS, ADI-R, CARS, ECA, EC2-R and ECF scores (data not shown). Also no correlation was recorded here with the presence of mental retardation either in the whole ASD sample $(U=117.0, p=0.65)$, or among ASD children $\leq 8$ years old $(U=31.0, p=0.71)$. The only clinical variables compatible with greater severity or with a pathomorphic effect of $p$-cresol and/or $p$-cresylsulfate are age at walking, as well as the observation of motor stereotypies and compulsive/repetitive behaviors at intake (Table 2).

\section{Discussion}

The primary aim of this study was to replicate in an ethnically distinct sample of ASD children and controls our initial report, demonstrating: (a) significantly higher urinary $p$-cresol concentrations among Italian ASD children compared with matched controls, (b) limited to children smaller than 8 years of age, (c) more frequently females and (d) more severely affected (Altieri et al., 2011). The present study replicates in an independent French sample both the statistically significant elevation of total urinary $p$-cresol in ASD patients compared with controls (Figure 1), and the strong age effect, restricting this elevation to a subset of small ASD children, aged $\leqq 8$ years of age (Figures 2 and 3). Two

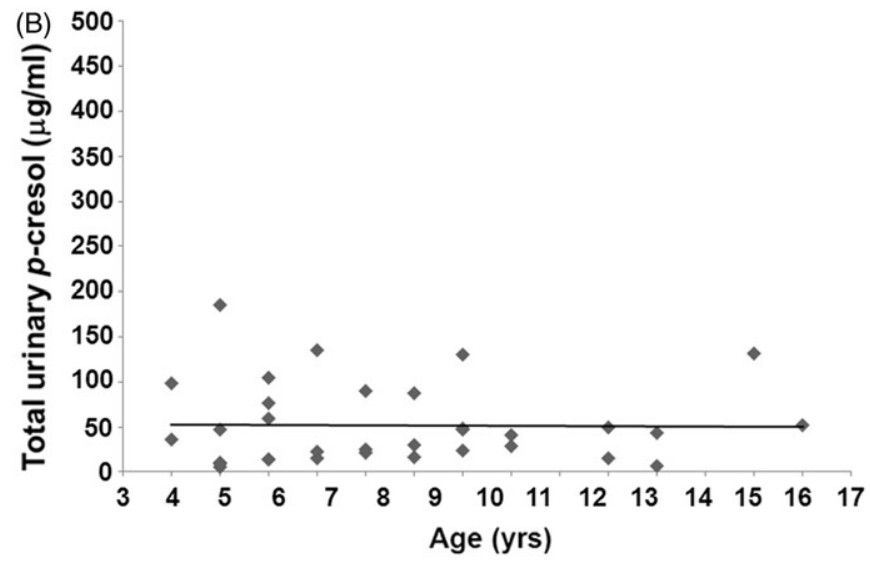

Figure 3. Total urinary $p$-cresol concentrations are negatively correlated with age $\left(\tau=-0.223, p<0.05\right.$, linear $\left.R^{2}=0.030\right)$ in $(\mathrm{A}) 33$ French $\mathrm{ASD}$ children, but not in (B) 33 age- and sex-matched typically developing controls $\left(\tau=0.079, p=0.51\right.$, linear $\left.R^{2}=-0.030\right)$. 
Table 2. Correlation between total urinary (A) p-cresol or (B) $p$-cresylsulfate levels and clinical characteristics in 33French ASD children.

\begin{tabular}{|c|c|c|c|}
\hline & \multicolumn{3}{|c|}{ Total urinary $p$-cresol } \\
\hline & $N$ & Mean \pm S.E.M. & $p$ \\
\hline \multicolumn{4}{|l|}{$\mathbf{A}$} \\
\hline \multicolumn{4}{|c|}{ Compulsive/repetitive behaviors at intake } \\
\hline Present & 14 & $139.9 \pm 37.0$ & 0.049 \\
\hline Absent & 19 & $68.9 \pm 13.7$ & \\
\hline \multicolumn{4}{|l|}{ Motor stereotypies at intake } \\
\hline Present & 14 & $121.1 \pm 26.5$ & 0.033 \\
\hline Absent & 19 & $63.6 \pm 18.2$ & \\
\hline \multicolumn{4}{|c|}{ Self-aggressive or self-injurious behavior at intake } \\
\hline Present & 5 & $63.6 \pm 18.2$ & 0.034 \\
\hline Absent & 27 & $121.1 \pm 26.5$ & \\
\hline \multicolumn{4}{|c|}{ History of neuropsychiatric disorders in first-degree relatives } \\
\hline Present & 24 & $81.4 \pm 21.2$ & 0.015 \\
\hline \multirow[t]{2}{*}{ Absent } & 8 & $146.7 \pm 34.6$ & \\
\hline & $N$ & $\tau$ & $p$ \\
\hline Age at walking, in months & 33 & 0.336 & 0.010 \\
\hline \multirow[t]{2}{*}{ Age at first social smile, in months } & 33 & -0.279 & 0.040 \\
\hline & \multicolumn{3}{|c|}{ Urinary $p$-cresylsulfate } \\
\hline \multicolumn{4}{|l|}{ B } \\
\hline \multicolumn{4}{|c|}{ Compulsive/repetitive behaviors at intake } \\
\hline Present & 14 & $131.2 \pm 35.3$ & 0.038 \\
\hline Absent & 19 & $64.5 \pm 14.2$ & \\
\hline \multicolumn{4}{|l|}{ Motor stereotypies at intake } \\
\hline Present & 14 & $112.4 \pm 25.3$ & 0.048 \\
\hline Absent & 19 & $61.1 \pm 19.6$ & \\
\hline \multicolumn{4}{|c|}{ Self-aggressive or self-injurious behavior at intake } \\
\hline Present & 5 & $31.6 \pm 10.7$ & 0.034 \\
\hline Absent & 27 & $102.7 \pm 19.8$ & \\
\hline \multicolumn{4}{|c|}{ History of neuropsychiatric disorders in first-degree relatives } \\
\hline Present & 24 & $74.5 \pm 18.9$ & 0.015 \\
\hline \multirow[t]{2}{*}{ Absent } & 8 & $146.7 \pm 34.6$ & \\
\hline & $N$ & $\tau$ & $p$ \\
\hline Age at walking, in months & 33 & 0.298 & 0.020 \\
\hline Age at first social smile, in months & 33 & -0.268 & 0.048 \\
\hline
\end{tabular}

children with particularly elevated $p$-cresol concentrations here support sliding the age cut-off from 8 to 8 years and a half (Figure 3A); however, also maintaining the $<8$ y.o. cut-off derived from Altieri et al. (2011), $p$ values are still $<0.05$ and 0.21 for children below and above this age threshold, respectively (Figure S1). Hence, the association of elevated urinary $p$-cresol with autism and the age effect are indeed replicated. Also, a trend toward females being more prone to developing high urinary $p$-cresol levels is present here, although the French sample includes only four female case-control pairs and is thus not fit for addressing sex effects.

The association between urinary $p$-cresol levels and autism severity found in the Italian sample (Altieri et al., 2011) represents the only correlation which has not been replicated in the French sample, although high urinary $p$-cresol and $p$-cresylsulfate concentrations are associated here with compulsive/repetitive behaviors, motor stereotypies at intake and age at walking onset (Table 2). The association between urinary $p$-cresol levels and autism severity found in Italian, but not in French ASD children, can conceivably be interpreted as spurious, dose-dependent, or due to the combined action of more than one gut-derived compound. A spurious association in our original study is indeed possible, given the number of clinical variables analyzed and the lack of statistical control for multiple testing. Possible dose-dependent effects receive some support from two pieces of evidence: (a) mean urinary $p$-cresol concentrations in Italian cases and controls were 123.5 and $91.2 \mu \mathrm{g} / \mathrm{ml}$, whereas in French cases and controls they are 98.8 and $52.0 \mu \mathrm{g} / \mathrm{ml}$, respectively (compare Figure 1 in Altieri et al. 2011 with Figure 1 here). Mean $p$-cresol levels in French ASD children are practically superimposable to those of Italian controls, while urinary $p$-cresol is clearly highest among Italian autistic children; (b) acute administration of high $(10 \mathrm{mg} / \mathrm{kg}$ i.v.), but not low ( $1 \mathrm{mg} / \mathrm{kg}$ i.v.) $p$-cresol, produces autistic-like behaviors in Black and Tan Brachyury (BTBR) mice, one of the most reliable rodent models of human ASD (Pascucci \& Persico, unpublished manuscript). Hence, dose-dependent effects of $p$-cresol on behavior cannot be dismissed. Finally, not only $p$-cresol, but also several urinary metabolites, either derived from gut bacteria or from environmental sources, result unbalanced in ASD (Emond et al., 2013; Mavel et al., 2013; Yap et al., 2010). Further metabolomic profiling of our ASD sample will thus be critical to understand whether and to what extent different combinations of gut-derived compounds including, but perhaps not limited to $p$-cresol, may collectively produce clinically relevant effects in ASD children from different ethnic backgrounds.

The present study extends our initial findings by measuring, in addition to total urinary $p$-cresol, also its three fractions, namely $p$-cresylsulfate, $p$-cresylglucuronate and free $p$-cresol. Our results confirm the approximate 95:4:1 ratio for $p$-cresol derivatives previously reported in most studies (Bone et al., 1976; Renwick et al., 1988). Controls display a slightly larger share of $p$-cresylsulfate compared with ASD cases, in line with previously documented limitations in sulfation capacity among autistic individuals (Alberti et al., 1999). In the present study, we observed a statistically significant increase in urinary $p$-cresylsulfate and $p$-cresylglucuronate in ASD children, whereas free $p$-cresol showed a non-significant trend (Figure 1B-D). Given the detection threshold of our methodology $(0.07 \mu \mathrm{g} / \mathrm{ml})$, results on free $p$-cresol should be seen with caution. Most importantly, $p$-cresylsulfate is the most abundant $p$-cresol derivative also among autistic individuals and it could conceivably represent the "true" toxin, as proposed in recent years for uremic toxicity initially attributed to free $p$-cresol. In particular, studies on uremic toxicity have demonstrated that $p$-cresylsulfate impairs functional mechanisms only partly overlapping with those affected by $p$-cresol. For example, $p$-cresol reduces oxygen-derived free radical production by granulocytes in vitro (De Smet et al., 2003), whereas $p$-cresylsulfate activates free radical production by leukocytes, boosting oxidative stress (Meert et al., 2012; Schepers et al., 2007). Elevated $p$-cresylsulfate levels in chronic kidney disease, as well as in diabetic nephropathy, have been associated with poor clinical outcome, due to endothelial damage and vascular calcifications eventually leading to coronary heart disease (Chiu et al., 2010; Liabeuf et al., 2010; Meijers et al., 2008; Wang et al., 2010, 2013). The elevated urinary concentrations of $p$-cresol and $p$-cresylsulfate found in a subset of small Italian and French autistic children 
are indeed within the range previously found to play clinically significant roles in patients with kidney failure (Liabeuf et al., 2010). Altogether, a greater involvement of $p$-cresylsulfate rather than of free $p$-cresol in autism is more compatible with our results. Their clinical and pathophysiological implications specifically within the context of small autistic children will merit further investigation.

In humans, urinary $p$-cresol originates from environmental sources and/or it is synthetized from tyrosine by some gut bacterial strains, primarily belonging to the Clostridium and Pseudomonas species (Cafaro et al., 2005; Selmer \& Andrei, 2001; for review see Persico \& Napolioni, 2012). A similar compound also linked to autism is represented by propionic acid, a behaviorally active short chain fatty acid also of environmental origin or produced in the gut by anaerobic bacteria, such as Clostridia and Propionibacteria (Al-Lahham et al., 2010; MacFabe et al., 2011). Another bacterial compound, 4-ethylphenylsulfate (4EPS), detected at high plasma levels in mouse models of ASD and sharing a surprising homology in chemical structure with $p$-cresol, promotes anxiety-like behaviors which are completely reverted by treatment with $B$. fragilis in rodents (Hsiao et al., 2013). This evidence, while supporting pathomorphic roles for gut-derived compounds in ASD or, at a minimum, their potential as biomarkers in small autistic children, does not address the origin of their accumulation. Conceivably, enhanced urinary $p$-cresol amounts could reflect either environmental exposure or gut infection with cresol-producing bacteria, or both. Within this framework, the difference in baseline urinary $p$-cresol between French and Italian typically developing children $(52.0 \pm 7.8$ versus $91.1 \pm 8.7 \mu \mathrm{g} /$ $\mathrm{ml}$, Student $t=2.994,90 \mathrm{df}, p<0.01$ ) could stem from differences in environmental exposure, since the Italian sample was entirely drawn from large cities (Rome and Naples), while the French sample was recruited in the less densely populated and more rural Loire region. On the other hand, Ethnic differences in baseline $p$-cresol excretion could also reflect differences in gut flora composition, presumably due to ethnic-specific nutrient intake (Holmes et al., 2008). Distinct dietary habits can in fact shape the gut microbiome (de Wouters et al., 2012) and could thus indirectly influence urinary $p$-cresol levels. In comparison to typically developing individuals, autistic children display additional levels of complexity: environmental exposure may be especially relevant to "picky eaters", who could absorb greater amounts of this compound by selecting cresol enriched foods; some parents could prefer administering food enriched in cresol antioxidants to their children, although this practice is relatively uncommon in Italy; autistic children with co-morbid intellectual disability may be more prone to bringing to their mouth objects covered with cresol-containing gloss. Meanwhile, also differences in gut bacterial composition between autistic and typically developing children may well yield enhanced synthesis of $p$-cresol in the gut lumen, resulting in more abundant urinary excretion of the compound. Within this framework, the age effect could be due to the maturation of the GI immune system and to its increasing ability to control the overgrowth of cresol-producing bacterial strains (Ashwood et al., 2006; Jyonouchi et al., 2005; Persico \& Napolioni, 2012). The present replication of elevated urinary $p$-cresol levels in an ethnically independent sample of autistic children encourages further investigations aimed at assessing the incidence of cresol-producing gut infections in our cohort and the mechanism boosting $p$-cresol levels in some small ASD children.

Interest into urinary $p$-cresol and/or its conjugated derivative forms is spurred not only by their toxicant effects, but also by their potential inclusion into a multi-biomarker panel for ASD in small children. Urinary $p$-cresol beyond highest control levels was recorded in 9/32 (28.1\%) and in 4/22 (18.2\%) Italian and French ASD children aged $<8$ years, respectively (Figure 3 in Altieri et al., 2011, and Figure 3A here). Given the heterogeneity of ASD and the specific etiopathogenic underpinnings present in each patient, multiple-biomarker panels able to foster earlier diagnoses and to predict clinical prognosis as well as treatment response will be very useful in clinical practice (Walsh et al., 2011). ASD complexity requires sexand age-specific panels, including biomarkers from different biological and physiological domains (Ruggeri et al., 2014). Furthermore, some racial and ethnic groups may require specific biomarker panels, accounting not only for genetic markers conferring ASD vulnerability, but also for differences in gut-derived compounds (Persico \& Napolioni, 2012). Preliminary results indicate that $p$-cresol may represent one of several compounds able to, collectively, distinguish small autistic children from controls with promising reliability (Neri et al., unpublished manuscript).

\section{Conclusions}

The present and previous results (Altieri et al., 2011), confirm that urinary amounts of the toxic compound $p$-cresol and of its derivatives, especially $p$-cresylsulfate, are significantly elevated in a sizable subgroup of small autistic children. These results were replicated in two case-control samples belonging to distinct ethnic groups, recruited in different geographical areas in Europe and screened at two independent clinical sites. Unbiased metabolomic and microbiomic approaches will have to define the degree of connection between elevated urinary $p$-cresol, skewed urinary metabolomic profiles and gut flora composition in our ASD patients. Clinical studies involving large cohorts will also be needed to conclusively define possible dose-dependent influences on the spectrum and severity of clinical signs and symptoms of ASD, as well as on endophenotypic subgroupings. Finally, perspective studies of high-risk infant siblings will be instrumental in determining the potential of urinary $p$-cresol and/or $p$-cresylsulfate as biological markers for an ASD diagnosis in small children and for predicting developmental trajectories.

\section{Acknowledgements}

The authors gratefully acknowledge all the families who participated in this study.

\section{Declaration of interest}

This work was financially supported by the Italian Ministry for University, Scientific Research and Technology (n.2008BACT54_002), the Italian Ministry of Health 
(CCM program 2012, progetto NIDA), the Fondazione Gaetano e Mafalda Luce (Milan, Italy), Autism Aid ONLUS (Naples, Italy), Autism Speaks (Princeton, NJ), the Autism Research Institute (San Diego, CA), and the European Union (Innovative Medicines Initiative Joint Undertaking, EU-AIMS, n. 115300). The authors declare no conflicts of interest. The authors alone are responsible for the content and writing of the paper.

\section{References}

Adrien JL, Roux S, Couturier G, et al. (2001). Towards a new functional assessment of autistic dysfunction in children with developmental disorders: the Behaviour Function Inventory. Autism 5:249-64.

Alberti A, Pirrone P, Elia M, et al. (1999). Sulphation deficit in "lowfunctioning" autistic children: a pilot study. Biol Psychiatry 46: $420-4$.

Al-Lahham SH, Peppelenbosch MP, Roelofsen H, et al. (2010). Biological effects of propionic acid in humans; metabolism, potential applications and underlying mechanisms. Biochim Biophys Acta 1801:1175-83.

Altieri L, Neri C, Sacco R, et al. (2011). Urinary p-cresol is elevated in small children with severe autism spectrum disorder. Biomarkers 16: 252-60.

American Psychiatric Association. (2013). Diagnostic and statistical manual of mental disorders. 5th ed. Arlington (VA): American Psychiatric Publishing.

Ashwood P, Wills S, Van de Water J. (2006). The immune response in autism: a new frontier for autism research. J Leukoc Biol 80:1-15.

Barthélémy C, Roux S, Adrien JL, et al. (1997). Validation of the revised behavior summarized evaluation scale. J Autism Dev Disord 27: 139-53.

Bergé-Lefranc D, Chaspoul F, Calaf R, et al. (2010). Binding of pcresylsulfate and $p$-cresol to human serum albumin studied by microcalorimetry. J Phys Chem B 114:1661-5.

Bone E, Tamm A, Hill M. (1976). The production of urinary phenols by gut bacteria and their possible role in the causation of large bowler cancer. Am J Clin Nutr 29:1448-54.

Bourreau Y, Roux S, Gomot M, et al. (2009). Validation of the repetitive and restricted behaviour scale in autism spectrum disorders. Eur Child Adolesc Psychiatry 18:675-82.

Brunet O, Lézin I. (1976). Le développement psychologique de la première enfance, $5^{\mathrm{e}}$ éd Issy-les-Moulineaux, Editions scientifiques et psychologiques.

Cafaro V, Notomista E, Capasso P, Di Donato A. (2005). Mutation of glutamic acid 103 of toluene o-xylene monooxygenase as a means to control the catabolic efficiency of a recombinant upper pathway for degradation of methylated aromatic compounds. Appl Environ Microbiol 71:4744-50.

Chiu CA, Lu LF, Yu TH, et al. (2010). Increased levels of total P-cresylsulphate and indoxyl sulphate are associated with coronary artery disease in patients with diabetic nephropathy. Rev Diabet Stud 7:275-84.

De Angelis M, Piccolo M, Vannini L, et al. (2013). Fecal microbiota and metabolome of children with autism and pervasive developmental disorder not otherwise specified. PLoS One 8:e76993.

De Bruin A. (1976). Metabolism of occupational agents. In: De Bruin A, ed. Biochemical toxicology of environmental agents. Amsterdam: Elsevier/North-Holland Biomedical Press, 87-170.

De Magistris L, Familiari V, Pascotto A, et al. (2010). Alterations of the intestinal barrier in patients with autism spectrum disorders and in their first-degree relatives. J Pediatr Gastroenterol Nutr 51:418-24.

De Smet R, Van Kaer J, Van Vlem B, et al. (2003) Toxicity of free p-cresol: a prospective and cross-sectional analysis. Clin Chem 49: $470-8$.

D’Eufemia P, Celli M, Finocchiaro R, et al. (1996). Abnormal intestinal permeability in children with autism. Acta Paediatr 85:1076-9.

Developmental Disabilities Monitoring Network Surveillance Year 2010 Principal Investigators; Centers for Disease Control and Prevention (CDC). (2014). Prevalence of autism spectrum disorder among children aged 8 years - autism and developmental disabilities monitoring network, 11 sites, United States, 2010. MMWR Surveill Summ 63:1-21. de Wouters T, Doré J, Lepage P. (2012). Does our food (environment) change our gut microbiome ('in-vironment'): a potential role for inflammatory bowel disease? Dig Dis 30:33-9

Emond P, Mavel S, Aïdoud N, et al. (2013). GC-MS-based urine metabolic profiling of autism spectrum disorders. Anal Bioanal Chem 405:5291-300.

Finegold SM, Molitoris D, Song Y, et al. (2002). Gastrointestinal microflora studies in late-onset autism. Clin Infect Dis 35:6-16.

Griffiths R. (1970). The abilities of young children. London: Child Development Center.

Holmes E, Loo RL, Stamler J, et al. (2008). Human metabolic phenotype diversity and its association with diet and blood pressure. Nature 453: 396-400.

Hsiao EY, McBride SW, Hsien S, et al. (2013). Microbiota modulate behavioral and physiological abnormalities associated with neurodevelopmental disorders. Cell 155:1451-63.

Jyonouchi H, Geng L, Ruby A, Zimmerman-Bier B. (2005). Dysregulated innate immune responses in young children with autism spectrum disorders: their relationship to gastrointestinal symptoms and dietary intervention. Neuropsychobiology 51:77-85.

Jyonouchi H, Geng L, Streck DL, Toruner GA. (2011). Children with autism spectrum disorders (ASD) who exhibit chronic gastrointestinal (GI) symptoms and marked fluctuation of behavioral symptoms exhibit distinct innate immune abnormalities and transcriptional profiles of peripheral blood (PB) monocytes. J Neuroimmunol 238: 73-80.

Keşli R, Gökçen C, Buluğ U, Terzi Y. (2014). Investigation of the relation between anaerobic bacteria genus clostridium and late-onset autism etiology in children. J Immunoassay Immunochem 35:101-9.

Leblond CS, Heinrich J, Delorme R, et al. (2012). Genetic and functional analyses of SHANK2 mutations suggest a multiple hit model of autism spectrum disorders. PLoS Genet 8:e1002521.

Liabeuf S, Barreto DV, Barreto FC, et al. (2010). Free p-cresylsulphate is a predictor of mortality in patients at different stages of chronic kidney disease. Nephrol Dial Transplant 25:1183-91.

Lord C, Rutter M, DiLavore PC, Risi S. (2002). ADOS, Autism Diagnostic Observation Schedule. Los Angeles (CA): Western Psychological Services [Italian version by Tancredi R, Saccani M, Persico AM, Parrini B, Igliozzi R, Faggioli R, eds. (2005). Florence, Italy: Organizzazioni Speciali].

MacFabe DF, Cain NE, Boon F, et al. (2011). Effects of the entericbacterial metabolic product propionic acid on object-directed behavior, social behavior, cognition, and neuroinflammation in adolescent rats: relevance to autism spectrum disorder. Behav Brain Res 217:47-54.

Mandel HG. (1971). Pathways of drug biotransformation: biochemical conjugations. In: LaDu BN, Mandel HG, Way EL, eds. Pathways of drug biotransformation. Baltimore (MD): Williams and Wilkins, $149-86$.

Mavel S, Nadal-Desbarats L, Blasco H, et al. (2013). ${ }^{1} \mathrm{H}_{-}{ }^{13} \mathrm{C}$ NMR-based urine metabolic profiling in autism spectrum disorders. Talanta 114:95-102.

Meert N, Schepers E, Glorieux G, et al. (2012). Novel method for simultaneous determination of $p$-cresylsulphate and $p$-cresylglucuronide: clinical data and pathophysiological implications. Nephrol Dial Transplant 27:2388-96.

Meijers BK, Bammens B, De Moor B, et al. (2008). Free p-cresol is associated with cardiovascular disease in hemodialysis patients. Kidney Int 73:1174-80.

Neri C, Gabriele S, Bernardini S, et al. Urine metabolic profiling of autistic children: insight into microbial metabolic impact. Unpublished manuscript.

OECD. (2003). m-/p-Cresol Category, Screening Information Data Set, Initial Assessment Report. Paris: UNEP Publications. Available from: www.chem.unep.ch/irptc/sids/oecdsids/m-pcresols.pdf.

Pascucci T, Persico AM. Effects of acute p-cresol administration in rodent models of human ASD. Unpublished manuscript.

Perron-Borrel. (1996). EDEI-R, échelles differentielles d'efficience intellecuelle-forme révisée. Paris, Editions du Centre de psychologique appliquée.

Persico AM, Merelli S. (in press). Key issues in mental health. Vol. 179/ Chapter 10

Persico AM, Napolioni V. (2012). Urinary p-cresol in autism spectrum disorder. Neurotoxicol Teratol 36:82-90. 
Persico AM, Napolioni V. (2013). Autism genetics. Behav Brain Res 251:95-112.

Ramakrishna BS, Roberts-Thomson IC, Pannall PR, Roediger WE. (1991). Impaired sulphation of phenol by the colonic mucosa in quiescent and active ulcerative colitis. Gut 32:46-9.

Renwick AG, Thakrar A, Lawrie CA, George CF. (1988). Microbial amino acid metabolites and bladder cancer: no evidence of promoting activity in man. Hum Toxicol 7:267-72.

Robertson MA, Sigalet DL, Holst JJ, et al. (2008). Intestinal permeability and glucagon-like peptide- 2 in children with autism: a controlled pilot study. J Autism Dev Disord 38:1066-71.

Ruggeri B, Sarkans U, Schumann G, Persico AM. (2014). Biomarkers in autism spectrum disorder: the old and the new. Psychopharmacology (Berl) 231:1201-16.

Rutter M, Le Couter A, Lord C. (2003). ADI-R, autism diagnostic interview - revised. Los Angeles (CA): Western Psychological Services [Italian version by Faggioli R, Saccani M, Persico AM, Tancredi R, Parrini B, Igliozzi R, eds. (2005). Florence, Italy: Organizzazioni Speciali].

Sacco R, Curatolo P, Manzi B, et al. (2010). Principal pathogenetic components and biological endophenotypes in autism spectrum disorders. Autism Res 3:237-52.

Schepers E, Meert N, Glorieux G, et al. (2007). p-cresylsulphate, the main in vivo metabolite of $p$-cresol, activates leucocyte free radical production. Nephrol Dial Transplant 22:592-6.

Schopler E, Reichler RJ, Rochen Renner BR. (1986). The Childhood Autism Rating Scale for diagnostic screening and classification of autism. New York (NY): Irvington.
Selmer T, Andrei PI. (2001). p-Hydroxyphenylacetate decarboxylase from Clostridium difficile. A novel glycyl radical enzyme catalysing the formation of $p$-cresol. Eur J Biochem 268:1363-72.

Walsh P, Elsabbagh M, Bolton P, Singh I. (2011). In search of biomarkers for autism: scientific, social and ethical challenges. Nat Rev Neurosci 12:603-12.

Wang CP, Lu LF, Yu TH, et al. (2010). Serum levels of total pcresylsulphate are associated with angiographic coronary atherosclerosis severity instable angina patients with early stage of renal failure. Atherosclerosis 211:579-83.

Wang CP, Lu LF, Yu TH, et al. (2013). Associations among chronic kidney disease, high total $p$-cresylsulfate and major adverse cardiac events. J Nephrol 26:111-18.

Wang Y, Kasper LH. (2014). The role of microbiome in central nervous system disorders. Brain Behav Immun 38:1-12.

Wang L, Christophersen CT, Sorich MJ, et al. (2011). Low relative abundances of the mucolytic bacterium Akkermansia muciniphila and Bifidobacterium spp. in feces of children with autism. Appl Environ Microbiol 77:6718-21.

Wechsler D. (2005). WISC-IV, échelle d'intelligence de Wechsler pour enfants, $4^{\mathrm{e}}$ ed. Paris: Editions du Centre de psychologie appliquée.

Whiteley P, Waring R, Williams L, et al. (2006). Spot urinary creatinine excretion in pervasive developmental disorders. Pediatr Int 48:292-7.

Yap IK, Angley M, Veselkov KA, et al. (2010). Urinary metabolic phenotyping differentiates children with autism from their unaffected siblings and age-matched controls. J Proteome Res 9:2996-3004.

Supplementary material available online

Supplementary Table S1 and Figure S1 